\title{
THE EFFECT OF TRADITIONAL HYGRO-THERMAL PRETREATMENTS ON THE ACOUSTICAL CHARACTERISTICS OF WHITE MULBERRY WOOD (Morus alba)
}

\author{
Aida Se Golpayegani ${ }^{1,2,3, \uparrow}$, Iris Brémaud ${ }^{I}$, \\ Marie-France Thevenon ${ }^{2}$, Kambiz Pourtahmasi ${ }^{3}$, Joseph Gril ${ }^{1}$
}

\begin{abstract}
The wood used in making musical instruments usually undergoes pre-treatments or conditioning. Some processes have resulted from laboratory research, while many treatments are applied by craftsmen using traditional methods that have not yet been scientifically assessed. This paper is based on laboratory methods which simulate hydrothermal pre-treatments traditionally applied by Iranian lute makers to mulberry (Morus alba), an important wood for lutes from the Middle East to Japan. By applying a cyclic process, drying $\left(60^{\circ} \mathrm{C}\right)$ and ambient re-conditioning, which mimics wood seasoning and short-term aging, the damping coefficient $(\tan \delta)$ was decreased down to $10 \%$ without negatively affecting specific modulus of elasticity (E\%). Long-term (up to 4 months) soaking in cold water removed extractives, and decreased density as well as E $/ \rho$, but did not affect tan $\delta$. Short-term hot water treatment removed as many extractives, but caused a smaller decrease in $E^{\prime} / \rho$ than cold water, and significantly increased $\tan \delta$. This paper helps to clarify some traditional processes used by instrument makers, and can provide a basis for necessary cross-cultural scientific studies in the future.
\end{abstract}

Keywords: Damping coefficient, extractives, vibrational properties, seasoning, water soaking.

\section{INTRODUCTION}

From ancient times until the present, wood has been used for a wide diversity of musical instruments. Each instrument carries a history of cultures, beliefs and experiments, through which its structure and way of choosing and processing the raw material has evolved. However, scientific research in the field of materials for musical instruments has focused on a few classical case studies from Western classical instruments (Bucur 2006), and the diversity of wood choices and processing have often been neglected (Brémaud 2012).

In recent decades, scientists have proposed many processes to enhance wood acoustic performance and dimensional stability through chemical modifications (Yano et al. 1994, Obataya et al. 2000). Treatments by simple natural compounds have also been evaluated (Petr and Ales 2014). However, craftsmen apply a variety of treatments, not only depending on cultures and types of instruments but also according to individual makers. In practice, the most economic and readily available treatments are based on water and heat. In addition, wood is almost always dried before beginning fabrication, typically through a slow process of natural air drying, which could be better described as seasoning or short-term aging. When using high temperature treatments, modification of cell-wall polymers cause changes in properties, depending

\footnotetext{
Laboratoire de Mécanique et Génie Civil (LMGC), CNRS UMR5508, Université Montpellier 2, Montpellier, France.

2 Research Unit Biomass, Wood, Energy, Bio-products, CIRAD PERSYST Department, Montpellier, France.

${ }^{3}$ Department of Wood and Paper Science and Technology, Faculty of Natural Resources, University of Tehran, Karaj, Iran.

^Corresponding author : aida.golpayegani@gmail.com

Received : 10.08.2014 Accepted : 21.07.2015
} 
on temperature, duration of treatment, and the level of moisture/water content (Kubojima et al. 2000, Placet et al. 2008, Obataya et al. 2006ab). Water also acts as a solvent that removes extractives, and the loss of some of these compounds can modify physico-mechanical properties (Obataya et al. 1999, 2000). Some mild (hygro-) thermal processes were also recently proposed for "improving" wood for guitar soundboards (Wagenführ et al. 2006) or imitating long-term natural aging for musical instruments (Noguchi et al. 2012).

The objective of the present study is to clarify how some traditional pre-treatments performed by craftsmen instrument makers affect wood acoustic properties. It is based on three processes applied by Iranian makers on white mulberry (Morus alba), which is a dominant species for making long-necked lutes in Iran (Se Golpayegani et al. 2012) as well as other types of lutes from the Middle East to Japan (Yoshikawa 2007). The authors previously reported on how the extractives of this species affected its dynamic mechanical properties (Se Golpayegani et al. 2012) and also its toxicity and allergenic sideeffects (Se Golpayegani et al. 2014). After interviewing some instrument makers, laboratory-scale protocols simulating traditional methods were applied to assess their effect on density $(\rho)$ and on the vibrational properties which are classically expressed by $E^{\prime} / \rho$ (specific modulus of elasticity, where $E^{\prime}$ : dynamic flexural modulus of elasticity and $\rho$ : Specific gravity) and damping coefficient $(\tan \delta)($ Ono and Norimoto 1984, Obataya et al. 2000).

\section{MATERIALS AND METHODS}

Figure 1 shows the sequence of treatments for samples from the two trees in the study.

\section{Material and conditioning}

White mulberry (Morus alba L.) is a semi porous hardwood with the varying density of $450-800 \mathrm{~kg} / \mathrm{m}^{3}$; with a yellowish brown heartwood and pale yellow sapwood, a normally straight grain and a moderately coarse texture pale yellow sapwood (Orwa et al. 2009). The wood from two trees was selected in Iran by a professional instrument maker, based on typical quality-grading criteria (mainly visual). All samples were taken from the medium heartwood.

Three $500 \times 50 \times 50 \mathrm{~mm}$ boards were cut from heartwood, and air dried for at least 6 months. Then, 120 specimens $(150 \times 15 \times 2 \mathrm{~mm}, \mathrm{~L} \times \mathrm{R} \times \mathrm{T})$ were cut. After a first measurement of their physical and vibrational properties, according to methods below, they were separated in different groups and submitted to treatments. Wood from Tree 1 underwent water-based treatments and wood from Tree 2 drying cycles (desorption/adsorption). When choosing the samples for each modality of treatment care was taken to prepare comparable groups of specimens within a given treatment (i.e. coming from the same board, having comparable range of properties etc).

All samples were first dried for $48 \mathrm{~h}$ at $60^{\circ} \mathrm{C}$, to reach stabilization in adsorption while avoiding drying damage. Samples were then conditioned for at least 3 weeks at $20 \pm 2^{\circ} \mathrm{C}$ and $65 \pm 5 \%$ RH before measuring vibrational properties; air-dry specific gravity $(\rho)$ and equilibrium moisture content (EMC). The same conditioning procedure was followed before and after each type and step of treatment. 


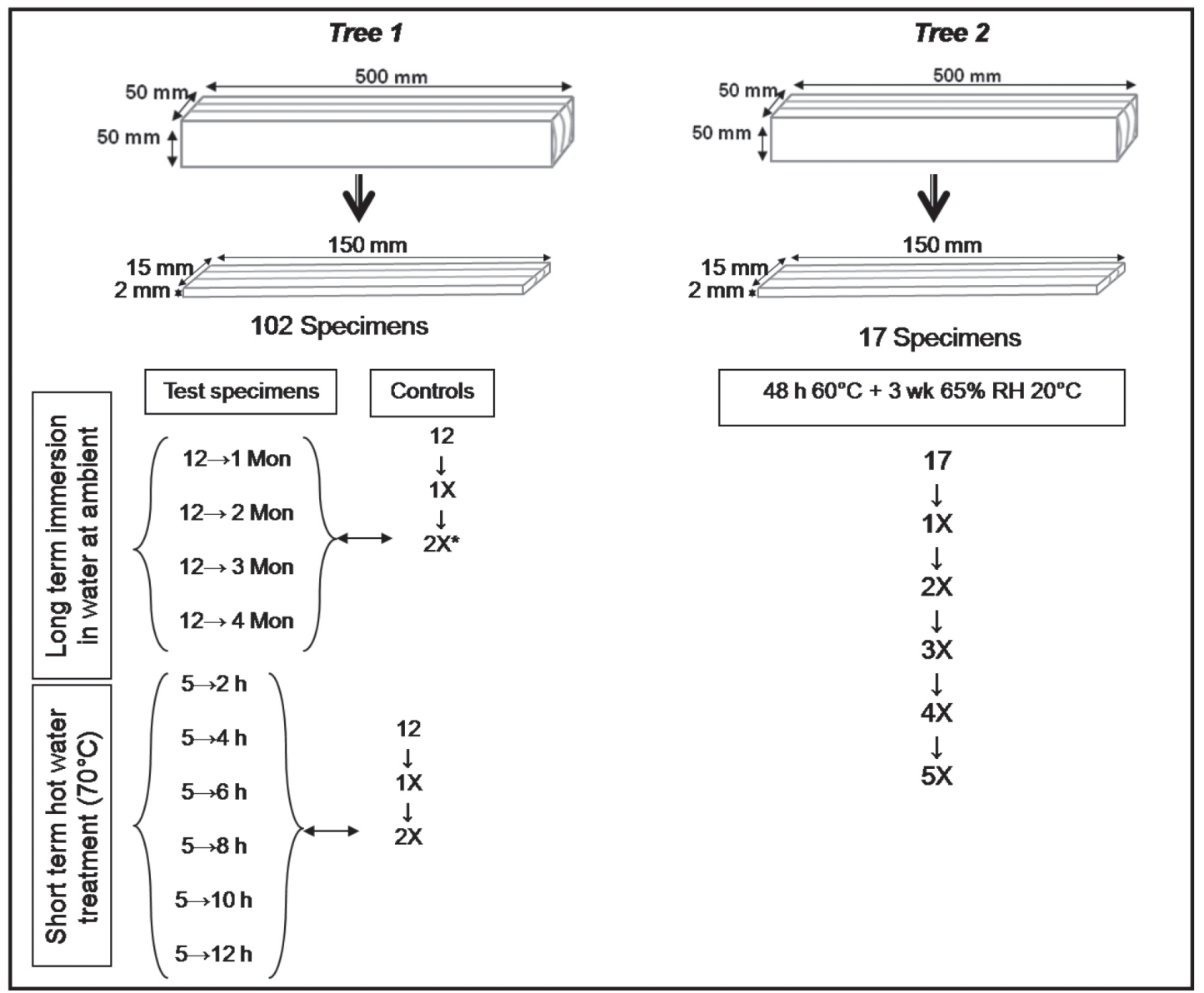

Figure 1. Schematic illustration of sample geometry and treatments used in this study *Specimens were independent for each time treatment, thus drying and conditioning were done only twice on the controls.

\section{Physical measurements}

At each step of treatment (untreated wood, different durations, and complete) semi-oven-dry ( $48 \mathrm{~h}$ at $60^{\circ} \mathrm{C}$ ) and air-dry $\left(3\right.$ weeks at $20^{\circ} \mathrm{C}$ and $\left.65 \% \mathrm{RH}\right)$ mass and dimensions were measured with a resolution of $0,001 \mathrm{~g}$ and $0,01 \mathrm{~mm}$ respectively. Specific gravity $(\rho)$ was calculated from mass and volume in these stabilized conditions. Equilibrium moisture content (EMC) was calculated from mass measured, at each step of treatment, at $65 \% \mathrm{RH}$ and after $60^{\circ} \mathrm{C}$ oven-drying. The residual moisture content after $48 \mathrm{~h}$ at $60^{\circ} \mathrm{C}$ was assessed by complete oven-drying at $103^{\circ} \mathrm{C}$ on a group of untreated samples, then at the end of treatments on the treated samples, and amounted to $1,4 \pm 0,5 \%$. After correction for this difference, the EMC at $65 \%$ RH of untreated mulberry was $8,1 \pm 0,3 \%$.

\section{Vibrational measurements}

Specific dynamic modulus of elasticity and damping coefficient were measured by non-contact forcedreleased vibrations of free-free slender beams (e.g. Obataya et al. 2000). The employed device and testing procedure are described in detail in Brémaud et al. 2012. 
Specimens, supported by thin threads located at nodal lines of the first bending mode, were set into flexural vibration using an electronic magnet facing a small piece of iron glued to one end of the specimen. The displacement at a belly of vibration was measured through a laser triangulation sensor (Figure 2).

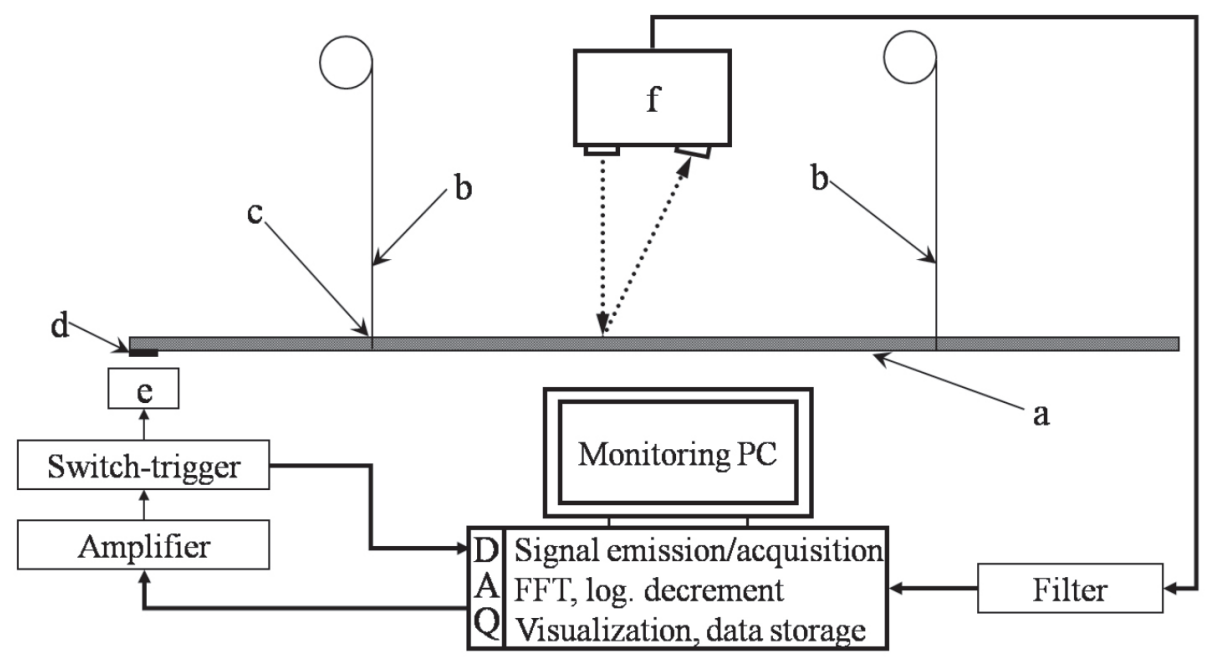

Figure 2. Device used for measuring vibrational properties; a: wood specimen; b: supporting threads; c: location of vibration nodes for 1st bending mode; d: thin steel piece glued onto one end of a specimen; e: triangulation laser displacement sensor ; f: capture for displacement.

Diagram from Brémaud (2012).

The emission of frequency sweeps and signal acquisition, processing and analysis were piloted through a development in Labview ${ }^{\circledR}$ software (Brémaud 2006, Brémaud et al. 2012). Specific dynamic modulus of elasticity $(E \% \rho$, calculated from first resonance frequency and dimensions measured at each step) and damping coefficient (tand, calculated both from the frequency bandwidth or "quality factor" and from the logarithmic decrement of amplitude after stopping the excitation) were determined as the average of three repetitions on each specimen. The frequency range was $200-400 \mathrm{~Hz}$.

\section{Hygroscopic cycling (mild oven drying - reconditioning)}

Seventeen specimens of Tree 2 were treated, with 8 specimens having narrow growth rings $(1,5-1,8 \mathrm{~mm}$; taken from a board of medium-outer heartwood) and 9 wider rings $(3,8-5,0 \mathrm{~mm}$; taken from a board of medium-inner heartwood). The drying $\left(48 \mathrm{~h}\right.$ at $\left.60^{\circ} \mathrm{C}\right)$ and conditioning $\left(\right.$ at $20^{\circ} \mathrm{C}$ and $\left.65 \% \mathrm{RH}\right)$ protocol was carried out five times, and for each cycle vibrational properties were measured after 3 weeks at $65 \% \mathrm{RH}$.

\section{Water treatments}

Considering that cumulated drying and re-saturation can affect wood viscosity and/or cause irreversible drying damage (Furuta et al. 1998), one aim was to separate those effects from water treatments themselves. Therefore, based on a pilot vibrational test, independent groups of specimens were matched and submitted to different treatment durations. Two different groups of 12 specimens each served as controls, i.e. they went through all the same physical and mechanical tests, but without being treated. Specimens for both water treatments, including their controls, had average growth rings of $\approx 3,8-5,0$ $\mathrm{mm}$. Calculation of changes in EMC and in $E^{\prime} / \rho$ took into account the mass loss from extraction as explained below. 


\section{Long term immersion in water at ambient temperature}

Four groups of 12 specimens each were placed in distilled water (water type 3 according to ISO 3696, 1995 ) at $20^{\circ} \mathrm{C}$, with water to wood proportion of 5:1 in volume. After 1, 2, 3 and 4 months, a group of specimens were taken out, air dried between wet paper for several days (to avoid warping or collapse), then oven dried $\left(60^{\circ} \mathrm{C}\right)$, re-conditioned, and re-subjected to vibrational tests.

\section{Short term hot water $\left(70^{\circ} \mathrm{C}\right)$ treatment}

Six groups of 5 specimens each were placed in distilled water at $70^{\circ} \mathrm{C}(5: 1$ water to wood ratio). The sample groups were heated for durations of $2,4,6,8,10$ and $12 \mathrm{~h}$. The drying procedure was as above: humid tissue drying + oven drying + conditioning + vibrational tests.

\section{Corrective factors and statistical analyses}

As water treatments can change mass and specific gravity by removing extractives, this contribution of extractives was taken into account for the calculation of changes in EMC according to Hernandez 2007, and for the calculation of changes in $E^{\prime} / \rho$ according to Brémaud et al. 2011 and Se Golpayegani et al. 2012.

All data were statistically analyzed using one way ANOVA test combined with Duncan Post-hoc in SPSS $^{\circledR}$ for $\alpha=0,05$ and $\alpha=0,01$.

\section{RESULTS AND DISCUSSION}

\section{Note on the variability of untreated mulberry wood}

Figure 3 shows the relationship between damping coefficient ( $\tan \delta)$ and specific modulus of elasticity $\left(E^{\prime} / \rho\right)$ for the untreated mulberry specimens. They generally have a lower tano, at given values of $E^{\prime} / \rho$, than would be expected from the "standard" trend established by Ono and Norimoto 1984. This lower $\tan \delta$ of mulberry was assigned to its heartwood extractives (Se Golpayegani et al. 2012). Specimens with dissimilar growth-ring width (sample intended for hygroscopic cycling) showed different properties. Those with narrow rings had lower $E^{\prime} / \rho$ and $\rho\left(E^{\prime} / \rho=12,5 \pm 0,7 \mathrm{GPa} ; \rho=0,45 \pm 0,01\right)$ and higher tan $\delta$ $\left(9,4 \pm 0,7 \times 10^{-3}\right)$ than specimens with wide rings $\left(E^{\prime} / \rho=16,1 \pm 1,0 \mathrm{GPa} ; \rho=0,55 \pm 0,01 ; \tan \delta=7,6 \pm 0,5 \times 10^{-3}\right)$. Lower specific gravity and modulus in narrow rings probably reflect the higher proportion of vessels due to the ring-porous anatomy. Mulberry wood has much lower $E$ '/ $\rho$ than Norway spruce selected for Western classical instruments which has a $E$ ' $/ \rho$ of 25-35 GPa (Yoshikawa 2007, Brémaud 2012), but its damping coefficient is only slightly higher in average. Furthermore, Morus alba wood selected as superior quality for the Japanese lute Biwa has clearly lower $E$ ' $\rho$ and higher tand than one qualified as "medium" (Yoshikawa 2007), which supports the hypothesis that the choice of mulberry rather than spruce is probably strongly related to cultural identity of Oriental instruments, i.e. different ways of playing and various musical tastes (Brémaud 2012). 


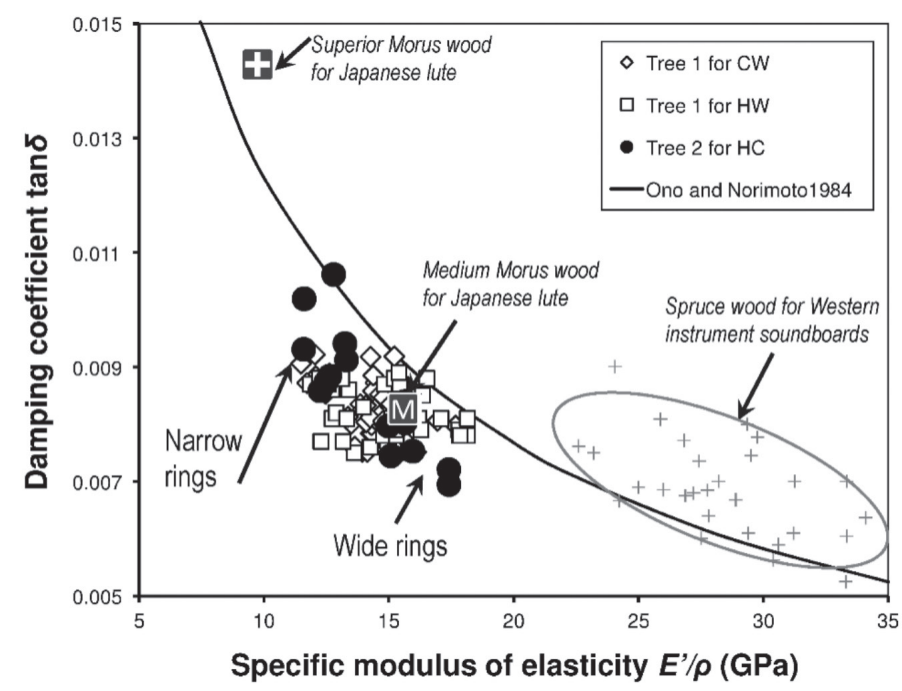

Figure 3. Relationship between damping coefficient $(\tan \delta)$ and specific modulus $\left(E^{\prime} / \rho\right)$ of untreated wood. Mulberry wood used in this study (Tree 1 and 2, CW: specimens for long-term cold water, HW: specimens for short-term hot water, HC: specimens for hygroscopic cycles) is compared to lutemaking mulberry wood from Japan (Yoshikawa 2007) and to Picea tone wood (Brémaud 2012).

\section{Changes in physico- mechanical characteristics from hygroscopic cycling}

After successive cycles of drying and re-stabilization, both $E$ ' $/ \rho$ and $\rho$ increased slightly (Figure 4), however these changes were not statistically significant (Table 1). Damping ( $\tan \delta)$ was more affected, decreasing down to $-10 \%$ of the original value.

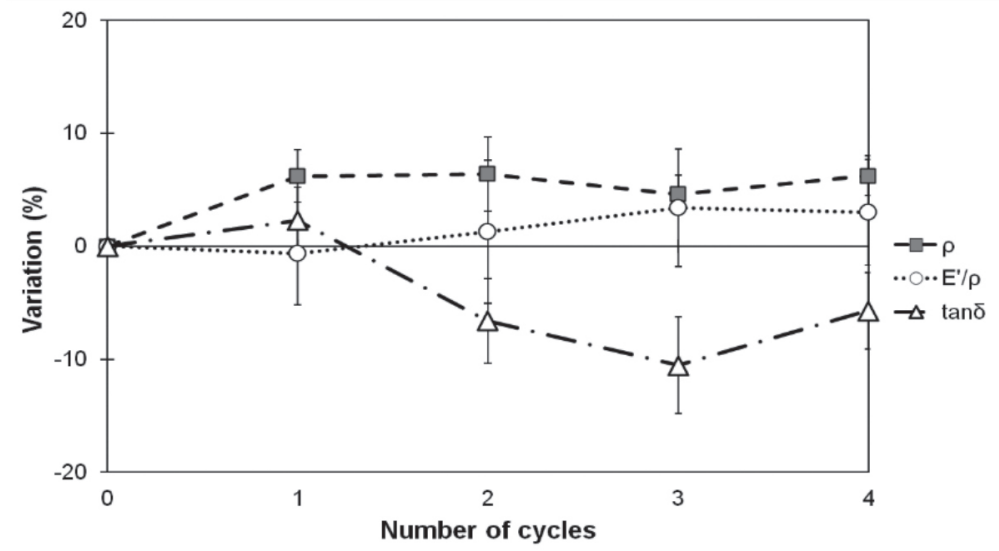

Figure 4. Variations in properties after submitting specimens to hygroscopic cycles. Changes in all cases are relative to the first measurement. 
Table1. Physical and vibrational properties of groups of specimens after hygroscopic cycling.

\begin{tabular}{|c|c|c|c|c|}
\hline Cycle $^{\circ}$ & $\mathrm{EMC}^{\mathrm{c}}(\%)$ & $\rho\left(\mathrm{kg} / \mathrm{m}^{3}\right)$ & $E^{\prime} / \rho(\mathrm{GPa})$ & $\begin{array}{c}\tan \delta \\
\left(10^{-3}\right)\end{array}$ \\
\hline 1 & $\begin{array}{c}7,8 \pm 0,1 \\
(\mathrm{ab})\end{array}$ & $0,51 \pm 0,04$ & $14,1 \pm 2,0$ & $\begin{array}{c}0,85 \pm 0,10^{*} \\
(\mathrm{a})\end{array}$ \\
\hline 2 & $\begin{array}{c}7,7 \pm 0,2 \\
(\mathrm{ab})\end{array}$ & $0,54 \pm 0,05$ & $14,6 \pm 2,4$ & $\begin{array}{c}0,87 \pm 0,10^{*} \\
(\mathrm{a})\end{array}$ \\
\hline 3 & $\begin{array}{c}7,2 \pm 0,2^{*} \\
(\mathrm{a})\end{array}$ & $0,53 \pm 0,05$ & $14,4 \pm 2,4$ & $\begin{array}{c}0,79 \pm 0,08 \\
(\mathrm{ab})\end{array}$ \\
\hline 4 & $\begin{array}{c}8,8 \pm 0,1 \\
(\mathrm{ab})\end{array}$ & $0,53 \pm 0,05$ & $15,1 \pm 2,5$ & $\begin{array}{c}0,76 \pm 0,07^{*} \\
(\mathrm{~b})\end{array}$ \\
\hline 5 & $\begin{array}{c}8,1 \pm 0,3^{*} \\
(\mathrm{~b})\end{array}$ & $0,54 \pm 0,04$ & $14,7 \pm 2,2$ & $\begin{array}{c}0,80 \pm 0,09 \\
(\mathrm{ab})\end{array}$ \\
\hline
\end{tabular}

*.significant at $\alpha: 0,05$.

$\mathrm{a}$ and $\mathrm{b}$ : inhomogeneous subsets.

c. EMC (equilibrium moisture content $(\%)$ : relative to $103^{\circ} \mathrm{C}$ oven-drying.

The "seasoned" wood - meaning a wood that undergoes changes in climate through drying and storage - is traditionally preferred by artisans and musicians. In the case of Iranian lutes, two methods of "seasoning" are common: (1) wood salvaged from other applications (e.g. doors or furniture) and reused for instruments (naturally seasoned) and ( 2 most common) wood left to be air-dried for several years by the instrument maker. Oscillating climates have been studied for industrial drying processes (Rémond et al. 2013). A reduction in EMC and of dimensional instability after humidity cycling, due to the partial saturation of the cell wall polar groups which leaves them unreachable for water vapor, was previously reported (Garcia Esteban et al. 2005). The present results show that damping also can be reduced by hygroscopic cycles.

\section{Water treatments: at ambient temperature and $70^{\circ} \mathrm{C}$ Effect of time and temperature on mass loss (ML)}

Figure 5 compares the mass losses (ML) from cold or warm water treatments of mulberry. Water is a known polar solvent for wood extraction which causes the mass losses. After immersion in water at ambient temperature (Figure 5-a) the ML was not statistically different between the different durations ( $\alpha$ : 0,05 ; average $\mathrm{ML} \approx 3,01 \pm 0,65$ between all four duration treatments). In hot $\left(70^{\circ} \mathrm{C}\right.$ ) water (Figure 5 -b), ML tended to increase gradually with duration of treatment (Significant at $\alpha: 0,05$ ). The maximum ML of both treatments was in the same range for long-term cold and short-term hot water treatments $(3,9 \% \pm 1,7$ and $3,3 \% \pm 0,8$; respectively).
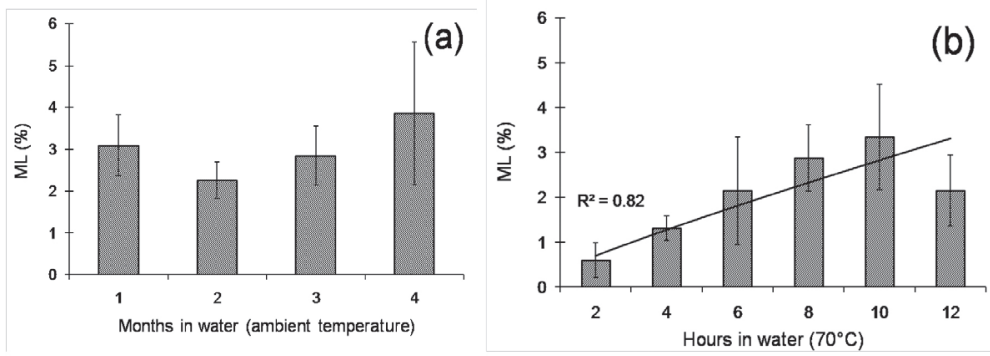

Figure 5. Oven-dry massloss (ML) after 1-4 months cold water soaking (a) and after 2-12 h of $70^{\circ} \mathrm{C}$ water treatment (b). In both cases, the samples were independent. 


\section{Effect of water-based treatments on physico-mechanical properties}

Long term water immersion had a small decreasing effect on specific modulus of elasticity (change of $-9 \%$ in $E \% / \rho$ for a change of $-4 \%$ in $\rho$, after 4 months) (Figure 6 -a). However, no significant trend against duration of long-term water immersion could be identified, neither for $\rho, E \% \rho$ nor for tan $\delta$ (Figure 6-b and Table 2). By comparison, on Norway spruce, which nevertheless has smaller extractives content than mulberry, a previous study also found no significant effect of long-term (3 months) water soaking on physical/mechanical properties (Sonderegger et al. 2008).

Table 2. Physical and vibrational properties of groups of specimens submitted to long-term water immersion.

\begin{tabular}{|c|c|c|c|c|c|c|c|c|}
\hline \multirow[t]{2}{*}{$\begin{array}{l}\text { Months in } \\
\text { the water }\end{array}$} & \multicolumn{2}{|c|}{$\begin{array}{c}\text { EMC }^{\mathrm{e}}(\%) \\
\text { Corrected } \\
\text { Apparent }\end{array}$} & \multicolumn{2}{|c|}{$\rho\left(\mathrm{kg} / \mathrm{m}^{3}\right)$} & \multicolumn{2}{|c|}{$\begin{array}{c}E^{\prime} / \rho(G P a) \\
\text { Corrected } \\
\text { Apparent }\end{array}$} & \multicolumn{2}{|c|}{$\tan \delta\left(10^{-3}\right)$} \\
\hline & Native & Treated & Native & Treated & Native & Treated & Native & Treated \\
\hline Control & $\begin{array}{l}7,9 \pm 0,2 \\
8,1 \pm 0,2\end{array}$ & $\begin{array}{c}8,9 \pm 0,1^{* *} \\
8,7 \pm 0,1 \\
\text { (c) }\end{array}$ & $0,57 \pm 0,02$ & $0,55 \pm 0,02$ & $\begin{array}{l}14,3 \pm 1,4 \\
14,0 \pm 1,0\end{array}$ & $\begin{array}{c}14,6 \pm 2,2 \\
13,7 \pm 1,6\end{array}$ & $0,85 \pm 0,06$ & $0,87 \pm 0,07$ \\
\hline 1 & $\begin{array}{l}8,0 \pm 0,1 \\
8,2 \pm 0,1\end{array}$ & $\begin{array}{c}8,9 \pm 0,3^{* *} \\
9,1 \pm 0,3 \\
\text { (d) }\end{array}$ & $0,56 \pm 0,03$ & $0,53 \pm 0,02$ & $\begin{array}{l}13,7 \pm 1,7 \\
13,6 \pm 1,3\end{array}$ & $\begin{array}{l}12,7 \pm 2,0 \\
12,5 \pm 1,8\end{array}$ & $0,83 \pm 0,06$ & $0,80 \pm 0,06$ \\
\hline 2 & $\begin{array}{l}8,1 \pm 0,2 \\
8,3 \pm 0,2\end{array}$ & $\begin{array}{c}8,5 \pm 0,2 * * \\
8,3 \pm 0,2 \\
\text { (b) }\end{array}$ & $0,57 \pm 0,02$ & $0,54 \pm 0,02$ & $\begin{array}{l}14,0 \pm 1,1 \\
13,7 \pm 1,1\end{array}$ & $\begin{array}{l}13,5 \pm 2,1 \\
12,9 \pm 1,7\end{array}$ & $0,82 \pm 0,06$ & $0,83 \pm 0,05$ \\
\hline 3 & $\begin{array}{l}8,0 \pm 0,2 \\
8,2 \pm 0,2\end{array}$ & $\begin{array}{c}7,6 \pm 0,2 * * \\
7,4 \pm 0,2 \\
\text { (a) }\end{array}$ & $0,57 \pm 0,02$ & $0,53 \pm 0,02$ & $\begin{array}{l}14,5 \pm 0,8 \\
14,3 \pm 0,8\end{array}$ & $\begin{array}{l}13,7 \pm 1,4 \\
13,5 \pm 1,2\end{array}$ & $0,82 \pm 0,05$ & $0,79 \pm 0,06$ \\
\hline 4 & $\begin{array}{l}7,8 \pm 0,7 \\
8,0 \pm 0,7\end{array}$ & $\begin{array}{c}7,7 \pm 0,3 * * \\
7,5 \pm 0,3 \\
\text { (a) }\end{array}$ & $0,57 \pm 0,01$ & $0,55 \pm 0,02$ & $\begin{array}{l}14,5 \pm 1,2 \\
14,2 \pm 0,8\end{array}$ & $\begin{array}{l}14,2 \pm 1,6 \\
13,4 \pm 1,0\end{array}$ & $0,83 \pm 0,05$ & $0,82 \pm 0,06$ \\
\hline
\end{tabular}

EMC: equilibrium moisture content (\%), $\rho$ : specific gravity, $E^{\prime} / \rho$ : specific modulus $(\mathrm{GPa})$

Native: Untreated samples which only went through physical steps (drying and conditioning) before vibrational test.

**. Significant at $\alpha: 0.01$.

$\mathrm{a}, \mathrm{b}$ and $\mathrm{c}$. inhomogeneous subsets

e. EMC relative to $103^{\circ} \mathrm{C}$ oven-drying. "Apparent" are measured values, "Corrected" is based on calculated oven-dry mass after the most efficient ( $4^{\text {th }}$ month) removal of extractives (Hernandez 2007)
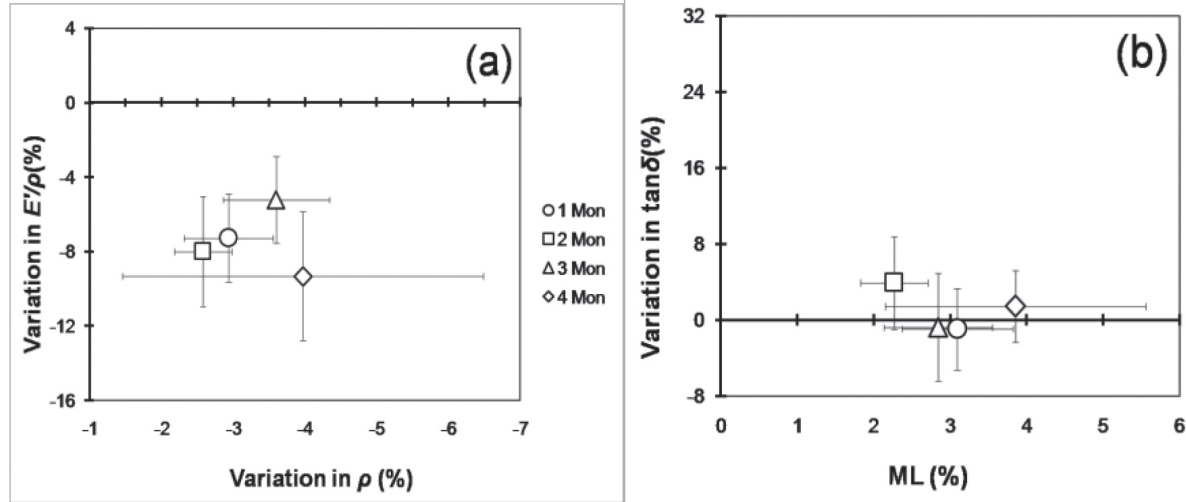

Figure 6.a) Relative changes in specific gravity $(\rho)$ and specific modulus of elasticity $\left(E^{\prime} / \rho\right)$ and b) mass loss and relative changes in tan $\delta$ after 1-4 months immersion in water at ambient temperature.

Demonstrated data were corrected for controls.

However, hot water $\left(70^{\circ} \mathrm{C}\right)$ treatment showed clear trends (Table 3). Both $E^{\prime} / \rho$ and tan $\delta$ were modified in a manner closely related to ML (Figure 7-a and b): a gradual decrease in $E$ ' $/ \rho$ (to $-4,5 \%$ ) along with 
$\rho$ (to $-3,5 \%$ ); and a gradual increase in damping related with ML (Figure 7-b). The alteration of trend after $12 \mathrm{~h}$ of treatment probably comes from i) different reaction of samples due to specimens being independent and ii) changes in cell wall because of long hours of hot water immersion (Jiang et al. 2009).

Table 3. Physical and vibrational properties of groups of specimens submitted to short term hot water $\left(70^{\circ} \mathrm{C}\right)$ treatment.

\begin{tabular}{|c|c|c|c|c|c|c|c|c|}
\hline \multirow[t]{2}{*}{$\begin{array}{c}\text { Hours of } \\
\text { treatment }\end{array}$} & \multicolumn{2}{|c|}{$\begin{array}{l}\text { EMC }^{\mathrm{d}}(\%) \\
\text { Corrected } \\
\text { Apparent }\end{array}$} & \multicolumn{2}{|c|}{$\rho\left(\mathrm{kg} / \mathrm{m}^{3}\right)$} & \multicolumn{2}{|c|}{$\begin{array}{c}E^{\prime} / \rho(G P a) \\
\text { Corrected } \\
\text { Apparent }\end{array}$} & \multicolumn{2}{|c|}{$\tan \delta\left(10^{-3}\right)$} \\
\hline & Native & Treated & Native & Treated & Native & Treated & Native & Treated \\
\hline Control $^{e}$ & $\begin{array}{l}8,4 \pm 0,5 \\
8,1 \pm 0,4 \\
\end{array}$ & $\begin{array}{c}8,0 \pm 0,2 * * \\
7,7 \pm 0,2 \\
\text { (a) }\end{array}$ & $0,55 \pm 0,03$ & $0,52 \pm 0,04$ & $\begin{array}{l}15,8 \pm 2,3 \\
13,9 \pm 1,6\end{array}$ & $\begin{array}{l}14,5 \pm 3,4 \\
13,5 \pm 2,5\end{array}$ & $\begin{array}{c}0,86 \pm 0,03^{* *} \\
\text { (b) }\end{array}$ & $0,79 \pm 0,05$ \\
\hline 2 & $\begin{array}{l}8,5 \pm 0,2 \\
8,2 \pm 0,2\end{array}$ & $\begin{array}{c}8,5 \pm 0,1^{* * *} \\
8,2 \pm 0,1 \\
\text { (b) }\end{array}$ & $0,57 \pm 0,01$ & $0,52 \pm 0,01$ & $\begin{array}{l}16,4 \pm 0,2 \\
14,2 \pm 0,4\end{array}$ & $\begin{array}{l}13,9 \pm 1,0 \\
13,1 \pm 0,7\end{array}$ & $\begin{array}{c}0,80 \pm 0,06^{* *} \\
(\mathrm{ab})\end{array}$ & $0,78 \pm 0,02$ \\
\hline 4 & $\begin{array}{l}8,3 \pm 0,2 \\
8,1 \pm 0,2\end{array}$ & $\begin{array}{c}8,7 \pm 0,4 * * \\
8,4 \pm 0,4 \\
\text { (b) }\end{array}$ & $0,59 \pm 0,02$ & $0,51 \pm 0,02$ & $\begin{array}{l}18,9 \pm 1,5 \\
15,7 \pm 0,8\end{array}$ & $\begin{array}{l}15,2 \pm 1,1 \\
14,6 \pm 0,7\end{array}$ & $\begin{array}{c}0,77 \pm 0,02 * * \\
\text { (a) }\end{array}$ & $0,78 \pm 0,03$ \\
\hline 6 & $\begin{array}{l}8,3 \pm 0,2 \\
8,1 \pm 0,2\end{array}$ & $\begin{array}{c}8,7 \pm 0,1 \\
8,3 \pm 0,1 \\
\text { (b) }\end{array}$ & $0,57 \pm 0,02$ & $0,51 \pm 0,01$ & $\begin{array}{l}16,8 \pm 1,7 \\
14,4 \pm 1,0\end{array}$ & $\begin{array}{l}15,9 \pm 0,5 \\
15,2 \pm 0,7\end{array}$ & $\begin{array}{c}0,79 \pm 0,03 * * \\
\text { (ab) }\end{array}$ & $0,79 \pm 0,04$ \\
\hline 8 & $\begin{array}{l}8,4 \pm 0,4 \\
8,2 \pm 0,4\end{array}$ & $\begin{array}{c}8,7 \pm 0,2^{* * *} \\
8,3 \pm 0,1 \\
\text { (b) }\end{array}$ & $0,56 \pm 0,01$ & $0,49 \pm 0,03$ & $\begin{array}{l}15,5 \pm 1,5 \\
13,7 \pm 1,1\end{array}$ & $\begin{array}{l}13,2 \pm 1,2 \\
13,2 \pm 1,5\end{array}$ & $\begin{array}{c}0,84 \pm 0,04 * * \\
\text { (ab) }\end{array}$ & $0,86 \pm 0,06$ \\
\hline 10 & $\begin{array}{l}8,4 \pm 0,2 \\
8,1 \pm 0,2\end{array}$ & $\begin{array}{c}8,8 \pm 0,1 * * \\
8,3 \pm 0,2 \\
\text { (b) }\end{array}$ & $0,56 \pm 0,01$ & $0,51 \pm 0,02$ & $\begin{array}{l}17,1 \pm 1,6 \\
15,0 \pm 1,0\end{array}$ & $\begin{array}{l}15,6 \pm 2,4 \\
15,0 \pm 1,9\end{array}$ & $\begin{array}{c}0,80 \pm 0,03^{* *} \\
(\mathrm{ab})\end{array}$ & $0,85 \pm 0,12$ \\
\hline 12 & $\begin{array}{l}8,2 \pm 0,2 \\
7,9 \pm 0,2\end{array}$ & $\begin{array}{c}8,6 \pm 0,2^{* *} \\
8,1 \pm 0,2 \\
\text { (b) }\end{array}$ & $0,55 \pm 0,02$ & $0,49 \pm 0,03$ & $\begin{array}{l}16,0 \pm 1,6 \\
14,2 \pm 1,1\end{array}$ & $\begin{array}{l}13,1 \pm 1,2 \\
13,1 \pm 0,5\end{array}$ & $\begin{array}{c}0,80 \pm 0,02 * * \\
(\mathrm{ab})\end{array}$ & $0,83 \pm 0,03$ \\
\hline
\end{tabular}

**. Significant at $\alpha: 0,01$

EMC: equilibrium moisture content (\%), $\rho$ : specific gravity, $E^{\prime} / \rho$ : specific modulus (GPa)

Native: Untreated samples which only went through physical steps (drying and conditioning) before vibrational test. $\mathrm{a}, \mathrm{b}$ and $\mathrm{c}$. inhomogeneous subsets

d. EMC relative to $103^{\circ} \mathrm{C}$ oven-drying. "Apparent" are measured values, "Corrected" is based on calculated oven-dry mass after the most efficient (10 hrs) removal of extractives (see Hernandez 2007).

e. Treated state for controls stands for values measured after one time of drying and stabilization.
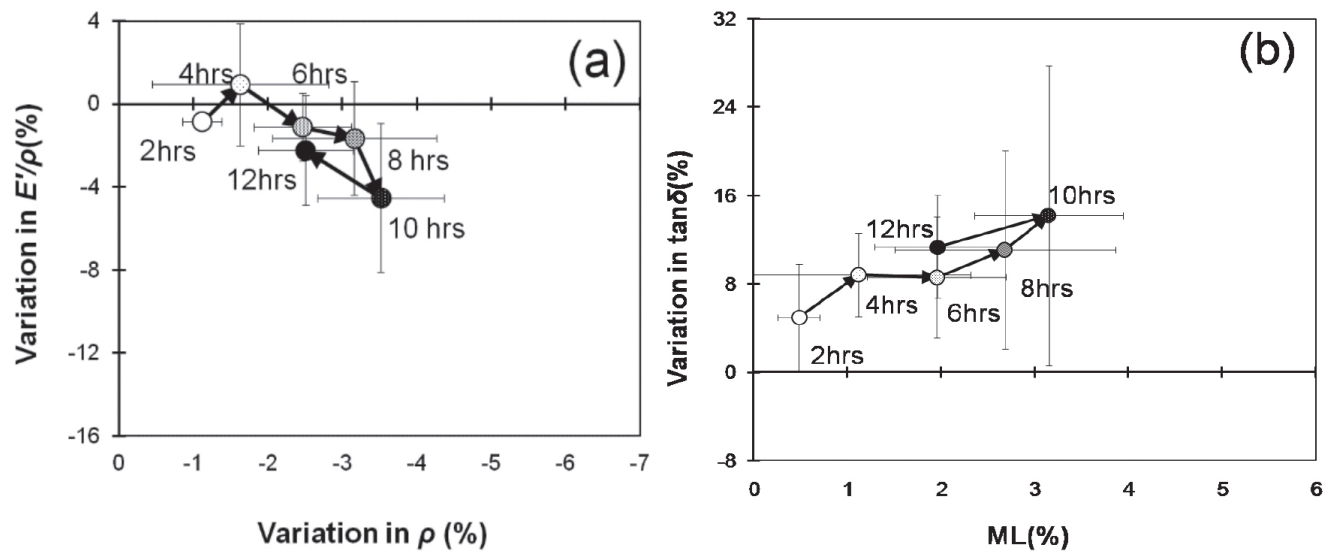

Figure 7.a) Relative changes in specific gravity $(\rho)$ and specific modulus of elasticity $\left(E^{\prime} / \rho\right)$ and b) mass loss and relative change in tand due to 2 to $12 \mathrm{~h}$ of hot $\left(70^{\circ} \mathrm{C}\right)$ water treatment. Demonstrated data were corrected for controls. 
There are two explanations of the contrasting effects of hot water (decrease in $E$ ' $/ \rho$, increase in $\tan \delta$ ) and cold water (decrease in $E^{\prime} / \rho$, nearly no change in tan $\delta$ ) treatments. Firstly, all changes could be from extractives removal. Water-soluble extractives are reported to have either decreasing or increasing effects on tand, (Obataya et al. 1999, 2000). For white mulberry wood, Se Golpayegani et al. 2012,

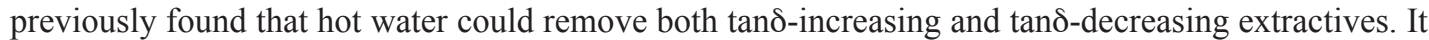
is possible that cold water reaches only compounds with no effects, whereas hot water could reach a broader spectrum including compounds that lower tan $\delta$ of untreated wood.

Secondly, the $70^{\circ} \mathrm{C}$ hygrothermal treatment may also affect wood constitutive polymers. Although significant degradation in hemicelluloses and lignin happens at temperatures higher than what was applied in this study, small degrees of changes can happen at lower temperatures if applied for longer time durations (Placet et al. 2008, Obataya et al. 2006a). Specific modulus of elasticity is also decreased by steam heat treatment (Obataya et al. 2006b), or increased by heat treatment in the absence of water (Kubojima et al. 2000). In the present study, cycles of dry heating $\left(60^{\circ} \mathrm{C}\right)$ tended to increase $E \% / \rho$ and decrease tan $\delta$, while heating in water $\left(70^{\circ} \mathrm{C}\right)$ had the opposite effect, but still resulted in less decrease in $E \%$ than for cold water. This may suggest a beginning of degradation in wood constituents together with extraction. However this would need to be confirmed by chemical analyses.

\section{Consequences in terms of acoustical indexes}

The properties studied in this paper characterize the vibrational behavior of wood material. However, to better describe the material contribution to acoustic response, "performances indexes" combining several properties have proposed (Wegst 2006). The "characteristic impedance" $z=c \rho=\sqrt{E^{\prime} \rho} \quad$ describes the ease of vibration transfer (e.g. from soundboard to air or from string to soundboard); the "radiation ratio" $R=\sqrt{E^{\prime} / \rho^{3}}$ describes the average loudness of sound; and the "acoustic conversion efficiency" $A C E=\sqrt{E^{\prime} / \rho^{3}} / \tan \delta$ the peak response.

Untreated white mulberry has a $\mathrm{z} \approx 2110 \pm 215, \mathrm{R} \approx 6,9 \pm 0,4$ and $\mathrm{ACE} \approx 832 \pm 75$. In terms of "amplitude of response" described by ACE and R (Wegst 2006), mulberry wood appears lower than spruce, the main soundboard material for violin, piano or guitar, with $\mathrm{ACE} \approx 1500-2500$ and $\mathrm{R} \approx 10-15$, while the impedance is in the lower part of the range of spruce $(\mathrm{z} \approx 2000-3000)$ (Brémaud 2012). A mulberry soundboard may be easier to set into vibration but radiates less. The three hygrothermal treatments affect these indexes in a maximum of $-10 \%$ to $+10 \%$ relative changes (i.e. the magnitude of change is comparable to natural variability), with different patterns for each treatment. Impedance is reduced by water treatments but increased by cyclic drying. ACE is reduced by hot water (not cold) and slightly increased by cyclic drying. $R$ is unchanged by water treatments but slightly decreased by cyclic drying. The cultural differences in instrument making and in musical preferences can dictate a desirable change from a particular treatment. The use of Mulberry as a key instrument -making material in Asia instead of spruce, which is preferred in Europe, accentuates such differences (Yoshikawa 2007, Brémaud 2012). If the "mulberry features" are to be enhanced (easy to set into vibration but low response), then hot water provides this combination. Cold water would go toward the "engineering view" of increasing both ease of vibration and radiation (slightly lower z and higher ACE). Cyclic drying appears "positive" (with reference to spruce for Western instruments) in terms of individual properties, but in terms of combined acoustical indexes it mostly increases z with little increase in "response indexes".

\section{CONCLUSIONS}

The results showed that:

Cyclic desorption/adsorption was able to decrease damping ( $\tan \delta)$ without negatively affecting specific modulus $\left(E^{\prime} / \rho\right)$, which may be a reason why makers generally prefer seasoned wood. 
Long-term water soaking at ambient conditions did not bring any significant change in tan $\delta$, although it removed some extractives and decreased $E^{\prime} / \rho$.

Short-time hot water treatment $\left(70^{\circ} \mathrm{C}\right)$ caused tan $\delta$ to increase and $E^{\prime} / \rho$ to decrease, from extractives removal possibly combined with early degradation of cell-wall constitutive polymers.

These results help to better understand the actual traditional treatments of wood. However, looking at the larger picture, differences in craftsmanship, musical cultures and instruments (How they are played and to what degree the wooden part is important in their final performance) must be taken into account, as it is obvious that white mulberry cannot be categorized using the same criteria as for Western tone woods such as resonance spruce. Furthermore, in the workshop, treatments are conducted on halfwaycarved pieces of wood for building Iranian lutes. On full dimensions, treatments could actually improve properties other than acoustical, such as dimensional stability or workability.

\section{ACKNOWLEDGMENTS}

Authors are grateful to Service de Coopération et d'Action Culturelle (SCAC) of the French embassy in Tehran and Center for International Scientific Studies and Collaboration (CISSC) for supporting this project (Gundishapur project, Egide nb 20714UJ). Authors are also grateful to Samad Zare, the professional Iranian lute maker who provided the raw material and shared his knowledge and experience through this study.

\section{REFERENCES}

Brémaud, I. 2006. Diversity of woods used or usable in musical instruments making. (In French), PhD thesis, University of Montpellier II. Montpellier, France, 302 p.

Brémaud, I. 2012. Acoustical properties of wood in string instruments soundboards and tuned idiophones: Biological and cultural diversity. Journal of the Acoustical Society of America 131(1) : 807-818.

Brémaud, I.; Amusant, N.; Minato, K.; Gril, J.; Thibaut, B. 2011. Effect of extractives on vibrational properties of African Padauk (Pterocarpus soyauxii Taub.). Wood Science and Technology 45(3): 461-472.

Brémaud, I.; El Kaïm, Y.; Guibal, D.; Minato, K.; Thibaut, B.; Gril, J. 2012. Characterisation and categorisation of the diversity in viscoelastic vibrational properties between 98 wood types. Annals of Forest Science 69: 373-386.

Bucur, V. 2006. Acoustics of wood. In: Timell TE, Wimmer R (eds) Springer series in wood science. Springer, Berlin.

Furuta, Y.; Norimoto, M.; Yano, H. 1998. Thermal-softening properties of water-swollen wood V. The effects of drying and heating histories. Mokuzai Gakkaishi 44:82-88.

Garcia Esteban, L.; Gril, J.; De Palacios, P.; Guindeo Casasus, A. 2005. Reduction of wood hygroscopicity and associated dimensional response by repeated humidity cycles. Annals of Forest Science 62:275-284.

Hernàndez, R.E. 2007. Moisture sorption properties of hardwoods as affected by their extraneous substances, wood density, and interlocked grain. Wood and Fiber Science 39:132-145.

ISO 3696. 1995. Water for analytical laboratory use. Specification and test methods.

Jiang, J.; Cai, Z.; Lu, J. 2009. Effect of Moisture Sorption State on Vibrational Properties of Wood. $16^{\text {th }}$ International symposium on nondestructive testing and evaluation of wood, Beijing, China. 
Kubojima, Y.; Okano, T.; Ohata, M. 2000. Vibrational properties of heat-treated green wood. Journal of Wood Science 46(1): 63-67.

Noguchi, T.; Obataya, E.; Ando, K. 2012. Effects of aging on the vibrational properties of wood. Journal of Cultural Heritage 13(3): (21-25).

Obataya, E.; Umezawa, T.; Nakatsubo, F.; Norimoto, M. 1999. The effects of water soluble extractives on the acoustic properties of reed (Arundo donax L.). Holzforschung 53(1): 63-67.

Obataya, E., Ono, T. ; Norimoto, M. 2000.Vibrational properties of wood along the grain. Journal of Materials Science 35: 2993-3001.

Obataya, E.; Shibutani, S.; Hanata, K.; Doi, S. 2006a. Effects of high temperature kiln drying on the practical performances of Japanese cedar wood (Cryptomeria japonica) I: changes in hygroscopicity due to heating. Journal of Wood Science 52(2): 111-114.

Obataya, E.; Shibutani, S.; Hanata, K.; Doi, S. 2006b. Effects of high temperature kiln drying on the practical performances of Japanese cedar wood (Cryptomeria japonica) II: changes in mechanical properties due to heating. Journal of Wood Science 52:111-114.

Orwa, C.; Mutua, A.; Kindt, R.; Jamnadass, R.; Anthony, S. 2009. Agro forestry Database: a tree reference and selection guide version 4.0. World Agro forestry Centre, Kenya.

Ono, T.; Norimoto, M. 1984. On physical criteria for the selection of wood for soundboards of musical instruments. Rheologica Acta 23: 652-656.

Petr, P.; Aleš, D. 2014. Moisture absorption and dimensional stability of poplar wood impregnated with sucrose and sodium chloride. Maderas. Ciencia y tecnología 16: 299-311.

Placet, V.; Passard, J.; Perré, P. 2008. Viscoelastic properties of wood across the grain measured under watersaturated conditions up to $135^{\circ} \mathrm{C}$ : evidence of thermal degradation. Journal of Materials Science 43:3210-3217.

Rémond, R.; De La Cruz, M.; Aléon, D.; Perré, P. 2013. Investigation of oscillating climates for wood drying using the flying wood test and loaded beams: need for a new mechano-sorptive model. Maderas. Ciencia y tecnología 15:269-280.

Se Golpayegani, A.; Brémaud, I.; Gril, J.; Thévenon, MF.; Arnould, O.; Pourtahmasi, K. 2012. Effect of extractions on dynamic mechanical properties of white mulberry (Morus alba L.). Journal of wood Science 58 (2):153-162.

Se Golpayegani, A. ; Thévenon, MF.; Gril, J.; Masson, E. ; Pourtahmasi, K. 2014. Toxicity potential in the extraneous compounds of white mulberry wood (Morus alba). Maderas. Ciencia y tecnología 16:227-238.

Sonderegger, W.; Alter, P.; Niemz, P. 2008. Investigations on selected properties of tonal wood of spruce from Grisons (Untersuchungen zu ausgewählten Eigenschaften von Fichtenklangholz aus Graubünden. Holz als Rohund Werkstoff 66:345-354.

Wagenführ, A.; Pfriem, A.; Grothe, T.; Eichelberger, K. 2006. Investigations on the characterisation of thermally modified spruce for sound boards of guitars (in German). Holz als Roh- und Werkstoff 64:313-316.

Wegst, UGK. 2006. Wood for sound. American Journal of Botany 93(10):1439-1448.

Yano, H.; Kajita, H.; Minato, K. 1994.Chemical treatment of wood for musical instruments. Journal of the Acoustical Society of America 96(6): 3380-3391.

Yoshikawa, S. 2007. Acoustical classification of woods for string instruments. Journal of the Acoustical Society of America 122:568-573. 